\title{
Towards practical earth abundant reduction catalysis: design of improved catalysts for manganese catalysed hydrogenation
}

Received 00th January 20xx, Accepted 00th January 20xx

DOI: $10.1039 / \times 0 \times x 00000 x$

\begin{abstract}
Magnus B. Widegren, Matthew L. Clarke*
Manganese catalysts derived from tridentate $P, N, N$ ligands can be activated easily using weak bases for both ketone and ester hydrogenations. Kinetic studies indicate the ketone hydrogenations are $0^{\text {th }}$ order in acetophenone, positive order in hydrogen and $1^{\text {st }}$ order in catalyst. This implies that the rate determining step of the reaction was the activation of hydrogen. New ligand systems with varying donor strength were studied and it was possible to make the hydrogen activation significantly more efficient; a catalyst displaying around a 3-fold increase in initial Turn-Over Frequencies for the hydrogenation of acetophenone relative to the parent system was discovered as a result of these kinetic investigations. Ester hydrogenations and ketone transfer hydrogenation (isopropanol as reductant) are first order for both the substrate and catalysts. Kinetic studies also gained insight into catalyst stability and identified a working range in which the catalysts is stable throughout the catalytic reaction (and a larger working range where high yields can still be achieved). The new more active catalyst, combining an electron-rich phosphine with an electron-rich pyridine is capable of hydrogenating acetophenone using as little as $0.01 \mathrm{~mol} \%$ catalyst at $65^{\circ} \mathrm{C}$. In all, protocols for reduction of 21 ketones and 15 esters are described.
\end{abstract}

\section{INTRODUCTION}

Homogenous hydrogenation of ketones and esters is used in synthesis, and in the large-scale production of important chemicals. Alongside enzymatic routes, homogeneous hydrogenation catalysed by $\mathrm{Ru}, \mathrm{Ir}$ and $\mathrm{Rh}$ are probably the core reactions used in the production of chiral alcohols in both the pharmaceutical, fine chemicals, and flavours and fragrance sector. ${ }^{1}$ In the best cases, these are very efficient reactions indeed, but in some cases the amount of precious metal catalyst used can be a major contributor to cost of a product, and even lead to these atom-efficient routes becoming unviable. Despite the impressive performance of ruthenium and iridium ketone hydrogenation catalysts, there has been a very strong drive to replace these metals with earth abundant metal alternatives. ${ }^{2}$ It is becoming clear there is untapped reactivity within earth abundant metal catalysts and hence many new opportunities to solve important problems of relevance to the chemical industry. Out of the earth abundant metal catalysts, manganese was almost ignored in hydrogenation catalysis until a seminal contribution from the Beller team demonstrated its promise. ${ }^{3}$ Since that paper there have been a number of articles published in the field of hydrogenation, ${ }^{4}$ and other reductive processes. ${ }^{4(\mathrm{~h}), 5}$ Practical reasons that make manganese an especially good candidate

\footnotetext{
${ }^{a .}$ School of Chemistry, University of St Andrews, St Andrews, KY16 9 ST, United Kingdom

† Footnotes relating to the title and/or authors should appear here.

Electronic Supplementary Information (ESI) available: [Further tables and graphs of results, full data, NMR and HPLC spectra e]. See DOI: 10.1039/x0xx00000x
}

relate to it being one of the most abundant metals and hence the amounts of $\mathrm{Mn}$ needed for the catalysis industry should be sustainable more or less indefinitely. Since manganese is classified as a metal of limited concern in terms of toxicity, the limits for $\mathrm{Mn}$ in pharmaceuticals are $250 \mathrm{ppm}$ relative to less than $10 \mathrm{ppm}$ for all precious metal catalysts. ${ }^{6}$ This might mean less energetic purification of products to reach the required specification, or might mean reactions that tend to need higher catalyst loadings of precious metal may become economic for $\mathrm{Mn}$, due to lower metal cost and lower purification cost. The use of manganese catalysts could lead to more sustainable hydrogenations. It is important to note that an earth abundant metal catalyst formed from bespoke ligands will still need to have significant activity (i.e. high TON) to be practical at larger scale. Advances that push earth abundant metal catalysts towards practicality are therefore urgently required, since it is only when these interesting approaches get used in commercial synthesis that the benefits regarding sustainability get properly realized. While $\mathrm{Mn}$ catalysed reductions are now being researched quite extensively, the majority of the papers make use of catalyst loadings in the range of $1-5 \mathrm{~mol} \%$. This is sometimes also accompanied by slightly less than ideal additives or solvents. In this article, we first describe the discovery of a chiral $\mathrm{Mn}$ catalyst for asymmetric ketone hydrogenation, development of more sustainable reaction conditions and synthetically useful ester hydrogenations. The use of kinetic studies was then used to develop a significantly more active second-generation catalyst that appears to be one of the most reactive of any earth abundant metal catalysts for the hydrogenation of ketones and esters. 


\section{RESULTS AND DISCUSSION}

As part of a programme studying a variety of metal catalysts derived from $P, N, N$ ligands for hydrogenations, ${ }^{7}$ we became interested in $\mathrm{Mn}$ complexes of ferrocene derived $P, N, N$ ligands. $^{8,41}$ We recently communicated that manganese catalyst $\left(\boldsymbol{S}_{c}, \boldsymbol{R}_{p}\right)-\mathbf{1}$ (Fig. 1 ) is a very promising hydrogenation catalyst. Selected previously communicated results are in Table 1 for comparative purposes. ${ }^{4(1), 4(q)}$

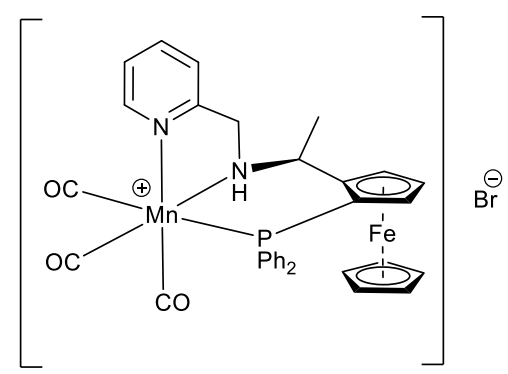

Fig. 1 Structure of manganese catalyst $\left(S_{c}, R_{p}\right)-1$

Using $1 \mathrm{~mol} \%\left(\boldsymbol{S}_{c}, \boldsymbol{R}_{p}\right)$-1 and $10 \mathrm{~mol} \% \mathrm{KO}^{t} \mathrm{Bu}$ we found that ketones could be successfully hydrogenated at moderate temperatures $\left(50{ }^{\circ} \mathrm{C}\right)$ in ethanol. We found that both the substitution on the phenyl ring as well as the alkyl side of the ketone had an impact on the enantioselectivity. Acetophenone and 4'-chloroacetophenone were reduced with low enantioselectivity under the unoptimized conditions (Table 1. Entry 1 and 2, er 60:40 and 62:38). However, both isobutyrophenone (entry 3 ) and 2'-chloroacetophenone (entry 4) could be reduced with significantly higher enantioselectivity (e.r. 91:9 and 79:21 respectively). For more examples see reference $4(I)$. The impact of base on both conversion and enantioselectivity has been studied (Table 2 and Table S1). Although the conversion after $4 \mathrm{~h}$ was found to be dependent on the base used, the impact on the enantioselectivity was minor (Table 2 and Table S1). We could not see any major differences with regards to the counter-ion under these conditions. There are sporadic examples of using weak bases like carbonates, or more commonly the use of pre-activated metal hydrides catalysts. ${ }^{9}$ The latter requires an extra synthetic step, often using a large excess of hydride reagent, to make the active catalyst that then tends to be less stable. Being able to use a simple precursor and a simple cheap base is desirable, but Ru or Ir catalysts derived from most $P, N, N$ ligands do not work well with bases weaker than alkoxides. ${ }^{7 c, d}$ We were very surprised by the performance possible using potassium carbonate as base, especially in ester hydrogenation. Potassium carbonate is a cheap and green choice of base relative to a metal alkoxides, and since it is significantly less basic than hydroxide, less water sensitive.
Table 1. Ketone hydrogenation using Mn catalysts

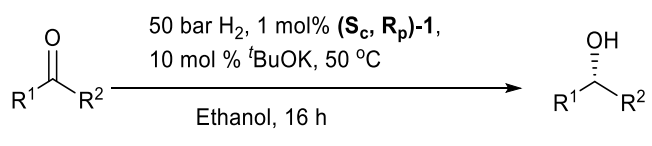

2a-d 3a-d

\begin{tabular}{cccccc}
\hline Entry & ketone & $\mathrm{R}^{1}$ & $\mathrm{R}^{2}$ & Conversion (\%) ${ }^{[\mathrm{b}]}$ & e.r. $^{[\mathrm{c}]}$ \\
\hline 1 & 2a & $\mathrm{Ph}$ & $\mathrm{CH}_{3}$ & $99(80)$ & $60: 40(R)$ \\
2 & 2c & $4-\mathrm{Cl}-\mathrm{Ph}$ & $\mathrm{CH}_{3}$ & $99(90)$ & $62: 38(R)$ \\
3 & 2b & $\mathrm{Ph}$ & $\mathrm{CH}\left(\mathrm{CH}_{3}\right)_{2}$ & $99(87)$ & $91: 9(R)$ \\
4 & 2d & 2-Cl-Ph & $\mathrm{CH}_{3}$ & $99(85)$ & $79: 21(R)$
\end{tabular}

a. Typical reaction conditions: $0.34 \mathrm{mmol}$ substrate, $0.003 \mathrm{mmol}$ catalyst, 0.034 $\mathrm{mmol}$ base and internal standard $(0.06 \mathrm{mmol})$ in $1.6 \mathrm{~mL}$ ethanol $(0.2 \mathrm{M})$ under 50 bar of $\mathrm{H}_{2}$ at $50{ }^{\circ} \mathrm{C}$ for $16 \mathrm{~h}$; b. Conversion was estimated by ${ }^{1} \mathrm{H}-\mathrm{NMR}$ using 1 methylnaphthalene as internal standard $(8-10 \mu \mathrm{L})$. Isolated yield in brackets; c. e.r. was measured using chiral HPLC, known absolute configuration in brackets;

Table 2. Investigation of different bases on reactivity ${ }^{a}$

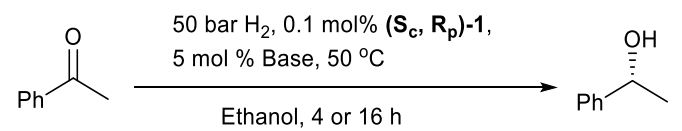

\begin{tabular}{ccccc}
\hline Entry & Base & Time (h) & Conv. (\%) & e.r. $^{\mathrm{c}}$ \\
\hline 1 & $\mathrm{KO}^{t} \mathrm{Bu}$ & 16 & $>99(80)$ & $75: 25(R)$ \\
2 & $-{ }^{\prime}-$ & 4 & $39(\mathrm{ND})$ & $81: 19(R)$ \\
3 & $\mathrm{~K}_{2} \mathrm{CO}_{3}$ & 16 & $>99(70)$ & $85: 15(R)$ \\
4 & $-{ }^{\prime}-$ & 4 & $37(\mathrm{ND})$ & $81: 19(R)$ \\
$5^{\mathrm{e}}$ & $-{ }^{-}-$ & 4 & $42(\mathrm{ND})$ & $81: 19(R)$ \\
6 & $\mathrm{NaO}^{t} \mathrm{Bu}$ & 4 & $43(\mathrm{ND})$ & $84: 16(R)$ \\
$7^{\mathrm{f}}$ & $-{ }^{-}{ }_{-}$ & 4 & $51(\mathrm{ND})$ & $81: 19(R)$ \\
8 & $\mathrm{Na}_{2} \mathrm{CO}_{3}$ & 4 & $16(\mathrm{ND})$ & $84: 16(R)$ \\
9 & $\mathrm{DBU}$ & 4 & $12(\mathrm{ND})$ & $89: 11(R)$ \\
$10^{\mathrm{g}}$ & $\mathrm{DBU}$ & 16 & $>99(90)$ & $80: 20(R)$
\end{tabular}

a. Typical reaction conditions: $2.10 \mathrm{mmol}$ substrate, $0.0021 \mathrm{mmol}\left(\boldsymbol{S}_{c}, \boldsymbol{R}_{p}\right) \mathbf{- 1}, 0.21$ $\mathrm{mmol}$ base and internal standard $(0.21 \mathrm{mmol})$ in $3.0 \mathrm{~mL}$ ethanol $(0.7 \mathrm{M})$ under 50 bar of $\mathrm{H}_{2}$ at $50{ }^{\circ} \mathrm{C}$ for 4 or $16 \mathrm{~h}$; b. Conversion was determined by ${ }^{1} \mathrm{H}-\mathrm{NMR}$ using 1 methylnaphthalene as internal standard $(8-10 \mu \mathrm{L})$. Isolated yield in brackets, ND = not determined; c. e.r. was measured using chiral HPLC, known absolute configuration in brackets; d. 1 mol\% 1 and 10 mol\% base used; e. $10 \mathrm{~mol} \% 18-\mathrm{C}-6$ used as additive; f. 2 mol\% base used; g. $0.2 \mathrm{~mol} \%\left(\boldsymbol{S}_{c}, \boldsymbol{R}_{p}\right)$-1.

There are other synthetic consequences of using a weaker base. Turning to ester hydrogenation, some substrates are incompatible with strong bases. Scheme 1 illustrates selected examples using potassium carbonate as the base in the hydrogenation of chiral esters. ${ }^{4(q)}$ Reference $4(q)$ show how, for example, (S)-Naproxen ethyl ester undergoes racemisation within a few minutes when exposed to the more common alkoxide bases, ${ }^{9(a)}$ but is stable to carbonate, and can be reduced clearly with very little racemization (Scheme 1 ). 


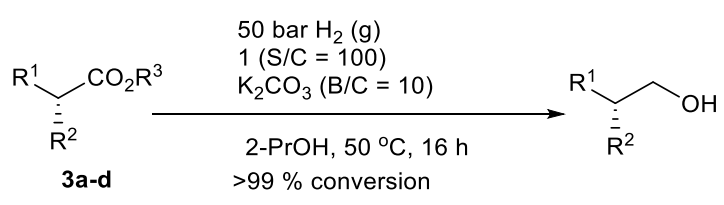<smiles>CCOC(=O)[C@H](C)c1ccc2cc(OC)ccc2c1</smiles>

$3 a$

$$
e e_{S M}=99 \%(S)
$$
$e e_{P d t}=97.5 \%(S)$<smiles>CCOC(C)c1ccc(C(C)(C)C)cc1</smiles>

3c $\quad$ ee $e_{S M}=99 \%(S)$ $e e_{P d t}=97.5 \%(S)$

$$
\begin{aligned}
& \approx \int_{\mathrm{NBn}_{2}}^{\mathrm{CO}_{2} \mathrm{Bn}} \\
& \text { 3e ee } \text { ee }_{S M}=99 \%(S) \\
& e e_{P d t}=99 \%(S)
\end{aligned}
$$

3b $\quad$ ee $e_{S M}=99 \%(S)$ $e e_{P d t}=97 \%(S)$<smiles>CCOC(=O)[C@H](CC)c1ccc(Cl)cc1</smiles>

3d $e_{S M}=99 \%(S)$ ee $e_{P d t}=97.5 \%(S)$

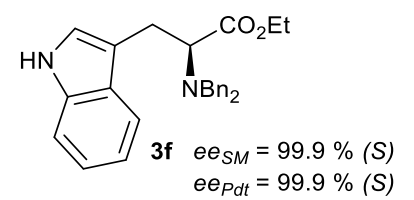

a. Typical conditions: $1.00 \mathrm{mmol}$ substrate, $0.010 \mathrm{~mol} 1,0.10 \mathrm{mmol} \mathrm{K}_{2} \mathrm{CO}_{3}, 50$ bar hydrogen gas, ethanol or isopropanol $(0.4 \mathrm{M}), 50{ }^{\circ} \mathrm{C}, 16 \mathrm{~h}$ using 1-methylnapthalene $(0.35 \mathrm{mmol})$ as internal standard; b. $110^{\circ} \mathrm{C}$.

Scheme 1. Selected examples of hydrogenation of chiral esters using inorganic base and catalyst 1 (previously communicated work) ${ }^{a}$

Preliminary studies using the original catalyst indicated that the hydrogenation of ethyl $p$-fluorobenzoate was first order in substrate, while the ketone hydrogenations had a superior fit for a reaction that was zero order in substrate. This implies that a step that doesn't involve the ketone is rate-limiting, and hence most likely catalysis that is limited by slow activation of dihydrogen. As such, we felt it likely that the catalytic activity might be responsive to changes in the donor strength of the tridentate ligands. Ligands derived from both a more electron donating phosphine such as di(4-methoxy-3,5-dimethylphenyl)phosphine, from here-on DMXPFA (Di(methoxyxylyl)phosphino derivative of PPFA, Scheme 2) or derived from a PPFA derivative containing the more electrondeficient di-(2-furyl)phosphine group (DFPFA, Scheme 2) allowed us to probe this hypothesis. To augment these electronic changes, a more electron donating and less electron donating pyridine unit was considered and we decided to investigate the impact of adding either a dimethylamino or a chloro group to the pyridine 4-position. The synthesis of the new ligands (4-8) followed already established protocols ${ }^{8(a), 8(e) \text {, }}$ 10 and are detailed below (Scheme 2). In short, the $N, N$ dimethyl phosphinoferrocenyl-1-ethylamine was reacted with acetic anhydride to form the acetate species with retention of stereochemistry. ${ }^{10(c)}$ This well studied substitution proceeds by assistance from the iron and is effectively a double inversion process. This species was then either displaced using 2aminomethylpyridine (ligands 4-5) or with ammonia to give the free amine again with retention.

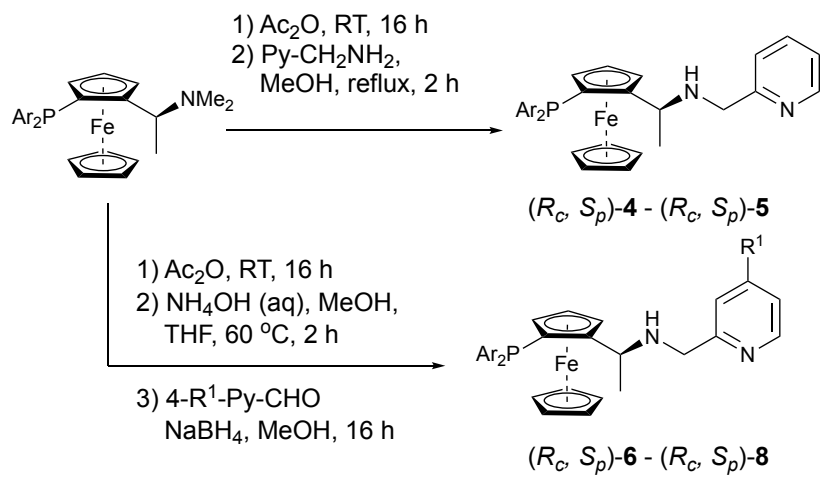

$\left(R_{c}, S_{p}\right)-4 ; \mathrm{Ar}=4$-methoxy-3,5-dimethylphenyl (DMXPFAPy),76\% yield $\left(R_{c}, S_{p}\right)-5 ; \mathrm{Ar}=2$-furyl (DFPFAPy), $61 \%$ yield

$\left(R_{c}, S_{p}\right)-6 ; \mathrm{Ar}=4$-methoxy-3,5-dimethylphenyl; $\mathrm{R}^{1}=\mathrm{NMe}_{2}\left(\mathrm{DMXPFAPy}{ }^{\mathrm{NMe} 2}\right), 85 \%$ yield

$\left(R_{c}, S_{p}\right)-7 ; \mathrm{Ar}=4$-methoxy-3,5-dimethylphenyl;

$\mathrm{R}^{1}=\mathrm{Cl}(\mathrm{DMXPFAPyCl}), 43 \%$ yield

$\left(R_{c}, S_{p}\right)-8 ; \mathrm{Ar}=2$-furyl;

$\mathrm{R}^{1}=\mathrm{NMe}_{2}\left(\right.$ DFPFAPy $\left.\mathrm{NMe}^{2}\right), 75 \%$ yield

Scheme 2. Synthesis of ligands 4-8 (overall yields starting from PPFA)

This free amine was then reductively alkylated with suitable 4substituted pyridine-2-carboxaldehyde to give ligands 6-8. The formed ligands were then reacted with $\operatorname{BrMn}(\mathrm{CO})_{5}$ in refluxing cyclohexane to give the manganese complexes as orange solids (Scheme 3 ).

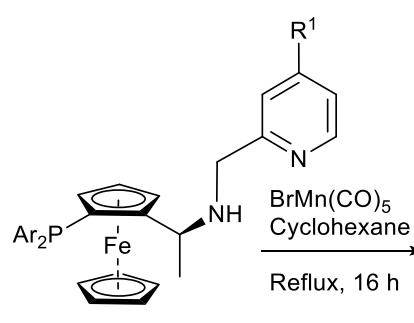

$\left(R_{c}, S_{p}\right)-4-8$

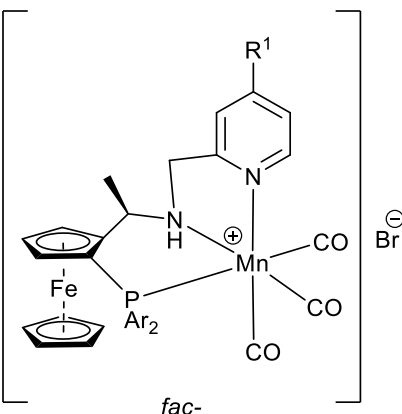

fac-

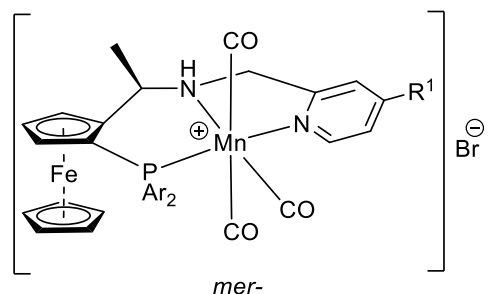

$\left(\boldsymbol{R}_{c}, \boldsymbol{S}_{\boldsymbol{p}}\right)$-9; $\mathrm{Ar}=4$-methoxy-3,5-dimethylphenyl, $\mathrm{R}^{1}=\mathrm{H}, 82 \%$ yield $\left(R_{c}, S_{p}\right)-10 ; A r=2$-furyl, $R^{1}=\mathrm{H}, 51 \%$ yield

$\left(\boldsymbol{R}_{c}, \boldsymbol{S}_{\boldsymbol{p}}\right)$-11; $\mathrm{Ar}=4$-methoxy-3,5-dimethylphenyl; $\mathrm{R}^{1}=\mathrm{NMe}_{2}, 92 \%$ yield $\left(R_{c}, S_{p}\right)$-12; $\mathrm{Ar}=4$-methoxy-3,5-dimethylphenyl; $\mathrm{R}^{1}=\mathrm{Cl}, 55 \%$ yield

$\left(R_{c}, S_{p}\right)-13 ; \mathrm{Ar}=2$-furyl; $\mathrm{R}^{1}=\mathrm{NMe}_{2}, 64 \%$ yield

Scheme 3. Synthesis of Mn complexes 9-13

For ligand 7 both $\left(R_{c} S_{p}\right)$ and $\left(S_{c} R_{p}\right)$ enantiomers were prepared. Catalyst $\mathbf{1}$ is sparingly soluble in most solvents and a pleasing secondary outcome was enhanced solubility for the new catalysts. Analysis of the full range of $\mathrm{Mn}$ complexes by 
NMR and IR spectroscopy enabled the geometry in alcohol solvents to be assigned with high confidence.

The reported crystal structure for $\left(S_{c}, R_{p}\right)-\mathbf{1} \mathbf{B A r}^{\mathrm{F}}$ was found to have a fac-coordination of the ligand around the $\mathrm{Mn}$ metal and showed a signal in the ${ }^{31} \mathrm{P}-\left\{{ }^{1} \mathrm{H}\right)-\mathrm{NMR}$ at $+45 \mathrm{ppm}$. This compound displays three bands in the carbonyl region of it's IR spectrum (2036.8, 1961.6 and $\left.1930.7 \mathrm{~cm}^{-1}\right){ }^{4(I)}$ The bromide complex $\left(S_{c}, R_{p}\right)-\mathbf{1}$ is sparingly soluble, making NMR analysis difficult, but in ethanol, the ${ }^{31} \mathrm{P}-\left\{{ }^{1} \mathrm{H}\right)-\mathrm{NMR}$ also displays a peak at around $+45 \mathrm{ppm}$. These are therefore assigned as the facial coordinated cationic complex. When $\left(S_{c}, R_{p}\right)-\mathbf{1}$ is isolated from a non-polar solvent, the IR spectrum in the solid state only displays 2 peaks at 1921 and $1842 \mathrm{~cm}^{-1}$, and when analysed by ${ }^{31} \mathrm{P}-\left\{{ }^{1} \mathrm{H}\right)-N M R$ in acetone as solvent, the only peak present is a $+90 \mathrm{ppm}$. The number of IR bands is often not diagnostic due to weak or overlapping peaks, but the presence of two bands at these wavenumbers is similar to a complex with meridional geometry with only two carbon monoxide ligands and bromide coordinated, reported by Milstein and co-workers. ${ }^{4 d}$ However, in contrast to reference $4 \mathrm{~d}, \mathrm{MS}$ analysis of $\left(S_{c}, R_{p}\right)$-1 shows the presence of three carbon monoxide ligands. In the case of the more soluble complex 11, (to be discussed further shortly) we found that you could switch between the $\delta_{p}=45 \mathrm{ppm}$ species and the $\delta_{\mathrm{p}}=90 \mathrm{ppm}$ species by removing solvents and redissolving in the other solvent. This would not be expected to be possible if the difference between the species involves loss of a carbon monoxide ligand. It is worth noting that in alcoholic solvents, as used in catalysis, the species present is fully consistent with the cationic facially coordinating ligand, and for this reason all complexes are drawn this way. A consistent trend emerges when the other complexes are examined by NMR and IR spectroscopy. Complex 11 was the most soluble complex and easiest to handle and will be discussed comparatively to complex $\mathbf{1}$, but similar observations were found for the other complexes. When $\mathbf{1 1}$ is isolated from a non-polar solvent, the solid state IR spectrum displays four carbonyl bands $\left(2025.3,1942.3,1905.9\right.$ and $1830.5 \mathrm{~cm}^{-1}$ ), while when dissolved in non-polar dichloromethane solvent, the ${ }^{31} \mathrm{P}-\left\{{ }^{1} \mathrm{H}\right.$ )-NMR spectrum showed two peaks (89 ppm and 44 ppm) in an 8:1 ratio. This is therefore consistent with a composite of the two species discussed for complex 1 , and as one might expect, all the $\mathrm{CO}$ bands are at somewhat lower wavenumber, since the ligand is more electron donating. When 11 is dissolved in methanol, only the $\delta_{p}=45 \mathrm{ppm}$ species is visible. The behaviour is analogous to $\mathbf{1}$, and also consistent with the pre-catalyst having a facially coordinating ligand, when dissolved in an alcoholic solvent as in every example of catalysis herein. The structure of the actual hydride species undertaking hydride transfer is unknown (as it is for almost all of the 100 s of hydrogenation catalysts!), although we favour a facial arrangement, as will be discussed later.

Table 3. Initial ketone hydrogenation investigation ${ }^{\mathrm{a}}$

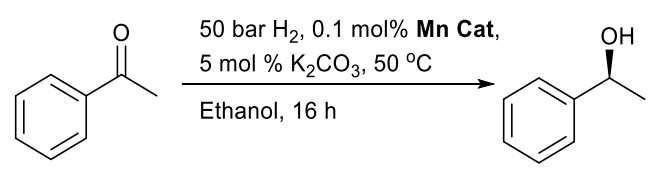

14

15

\begin{tabular}{cccc}
\hline Entry & Cat & ${\text { Conversion }(\%)^{\mathrm{b}}}$ & $\mathrm{er}^{\mathrm{c}}$ \\
\hline 1 & $\left(R_{c}, S_{p}\right)-\mathbf{9}$ & $>99(\mathrm{ND})$ & $81: 19(S)$ \\
2 & $\left(R_{c} S_{p}\right)-\mathbf{1 0}$ & $83(\mathrm{ND})$ & $84: 16(S)$ \\
3 & $\left(R_{c}, S_{p}\right)-11$ & $>99(98)$ & $84: 16(S)$ \\
4 & $\left(R_{c}, S_{p}\right)-\mathbf{1 2}$ & $83(\mathrm{ND})$ & $83: 17(S)$ \\
5 & $\left(R_{c}, S_{p}\right)-\mathbf{1 3}$ & $>99(\mathrm{ND})$ & $88: 12(S)$
\end{tabular}

a. Experimental conditions: $3.1 \mathrm{mmol}$ acetophenone, $0.0031 \mathrm{mmol}$ catalyst, 0.15 mmol $\mathrm{K}_{2} \mathrm{CO}_{3}, 50$ bar $\mathrm{H}_{2}, 50{ }^{\circ} \mathrm{C}, 16 \mathrm{~h}$, ethanol $(0.62 \mathrm{M})$; b. determined by $1 \mathrm{H}-\mathrm{NMR}$ using internal standard, isolated yields in brackets; c. determined by chiral HPLC, known configuration in brackets.

Initial tests established how the new catalysts performed in hydrogenation using acetophenone (14) as the substrate. Table 3 shows the results. The reaction conditions used just 0.1 mol\% catalyst, 5 mol\% $\mathrm{K}_{2} \mathrm{CO}_{3}$ and a reaction time of $16 \mathrm{~h}$ under $50{ }^{\circ} \mathrm{C}$ and 50 bar $\mathrm{H}_{2}$ in ethanol. The initial investigation showed that electron-poor phosphines had a detrimental impact on the catalytic activity. Interestingly, the data suggest that the impact on enantioselectivity is minimal regardless of substitution on the phosphine or the pyridine (4-position).

To further investigate the impact of ligand structure on the catalyst activity kinetic studies on the hydrogenation of acetophenone were carried out (Table 4 and Fig. 2). These were carried out at the less effective pressure of 20 bar (for technical reasons), with pressure kept constant and topped up with a gas burette, the rate of which was measured. The kinetic data shown in Table 4 show that, compared to $1, \mathrm{Mn}$ complexes with an electron-rich phosphine (9) increase the rate of conversion a little, but that an electron-poor phosphine (10) reduce the rate of conversion. The impact on the activity when the ligand has an electron-donating group in the 4position of the pyridine, as well as the donating (dimethoxyxylyl)phosphino group, (11) is significantly faster rates of reaction (around 3 times faster than 1). A ligand with an electron-withdrawing group (12) in the 4-position of the pyridine, but an electron-rich (dimethoxy-xylyl)phosphino group gives catalysts with diminished rates relative to the parent catalyst with unsubstituted pyridine, 9. Adding an electron-donating group in the pyridine 4-position, combined with the electron-poor difurylphosphino group, (13) not only showed an increase in rate of conversion compared to the other difurylphosphino containing ligand, 10, but proved to be more active than the original catalyst $\mathbf{1}$. This indicates that the electronics of the pyridine are more important to activity than the nature of the phosphine (Fig S1 and S2). The TOF highlighted the difference more clearly (Table 4 entries 1,3 and 6). 
Table 4. Effect of catalyst electronics on the hydrogenation of acetophenone $^{\mathrm{a}}$

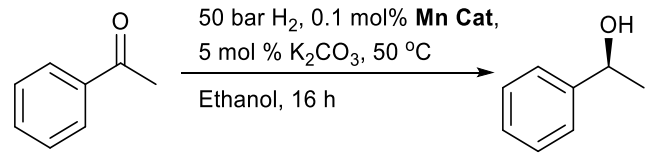

14

\begin{tabular}{ccccc}
\hline Entry & Cat & ${\text { TOF }\left(\mathrm{h}^{-1}\right)^{\mathrm{b}}}$ & $\mathrm{t}_{1 / 2}(\mathrm{~h})^{\mathrm{c}}$ & ${\text { Conv. }(2 \mathrm{~h})(\%)^{\mathrm{d}}}^{\mathrm{d}}$ \\
\hline 1 & $\mathbf{1}$ & 69 & 6.7 & 11.5 \\
2 & $\mathbf{9}$ & 112 & 4.7 & 22.6 \\
3 & 10 & 35 & 15.4 & 11.0 \\
4 & $\mathbf{1 1}$ & 200 & 2.6 & 38.7 \\
5 & $\mathbf{1 2}$ & 77 & 6.4 & 17.6 \\
6 & 13 & 85 & 4.8 & 15.2 \\
$7^{\mathrm{e}}$ & $\mathbf{1}$ & 47 & $\mathrm{~N} / \mathrm{A}$ & 9.0 \\
$8^{\mathrm{e}}$ & $\mathbf{9}$ & 90 & $\mathrm{~N} / \mathrm{A}$ & 18.0 \\
$9^{\mathrm{e}}$ & $\mathbf{1 0}$ & 24 & N/A & 5.0 \\
$10^{\mathrm{e}}$ & $\mathbf{1 1}$ & 283 & N/A & 57.0 \\
$11^{\mathrm{f}}$ & $\mathbf{1 1}$ & 325 & N/A & 26.0
\end{tabular}

a. experimental conditions: entries 1-6: $20.81 \mathrm{mmol}$ acetophenone, $0.021 \mathrm{mmol}$ catalyst, $1.04 \mathrm{mmol} \mathrm{K}_{2} \mathrm{CO}_{3}, 20$ bar $\mathrm{H}_{2}, 50{ }^{\circ} \mathrm{C}, 16 \mathrm{~h}$, ethanol $(0.62 \mathrm{M})$, entries 7-11: $3.1 \mathrm{mmol}$ acetophenone, $0.0031 \mathrm{mmol}$ catalyst, $0.15 \mathrm{mmol} \mathrm{K}_{2} \mathrm{CO}_{3}, 50$ bar $\mathrm{H}_{2}, 50$ ${ }^{\circ} \mathrm{C}$, $2 \mathrm{~h}$, ethanol (0.62 M); b. for entries 1-6: calculated at $25 \%$ conversion, with entry 4 an average of 3 expts. (see ESI Table S2); for entries 7-10 calculated after $2 \mathrm{~h}$ reaction time; c. time at which $50 \%$ conversion was achieved; $\mathrm{d}$. Conversion after $2 \mathrm{~h}$ reaction time; e. reaction carried out in vials using $3.1 \mathrm{mmol}$ acetophenone, $0.0031 \mathrm{mmol}$ catalyst, $0.15 \mathrm{mmol} \mathrm{K}_{2} \mathrm{CO}_{3}, 50$ bar $\mathrm{H}_{2}, 50{ }^{\circ} \mathrm{C} \mathrm{EtOH}$ (1.2 M), 2 h; f. Reaction run at $70{ }^{\circ} \mathrm{C}$ using 0.04 mol\% 11.

The use of an electron-rich phosphine together with an electron-donating group in the pyridine 4-position (e.g. 11) showed around a 3-fold increase in rate compared to $\mathbf{1}$ (Table 4 and Fig. 2). The less-active, 1 was already demonstrated to be significantly more active than other ketone hydrogenation catalysts based on $\mathrm{Mn}^{41,9}$ Separate 'batch' experiments measuring conversion after $2 \mathrm{~h}$ (Table 4, entries 7-10 and Fig. S3) showed a similar trend as the gas-uptake measurements; electron-donating substituents increases reaction rate.

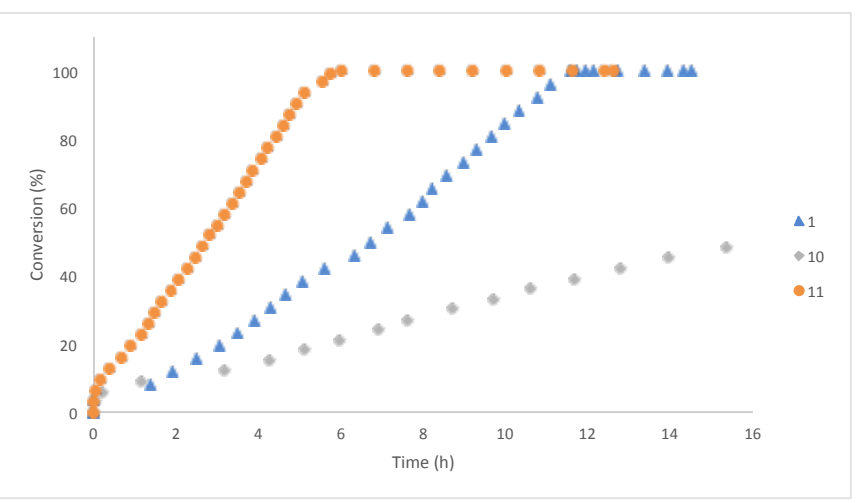

Fig. 2. Conversion over time for the hydrogenation of acetophenone at 20 bar $\mathrm{H}_{2}$ using $\mathrm{Mn}$ complexes $\mathbf{1 0}$ and $\mathbf{1 1}$ compared with $\mathbf{1}$. The data from catalyst $\mathbf{1 1}$ is an average of three runs (see ESI Table S2)
The electronics of both the pyridine and the phosphine has an impact on the catalytic activity of the $\mathrm{Mn}$ complex due to facilitating hydrogen activation. All reactions were zero order in ketone (as illustrated by essentially constant rates regardless of substrate concentration in Fig. 2). Hence hydrogen activation should be rate-determining in acetophenone hydrogenation. The order in catalyst was determined using Burés method to be 1 (Fig. S4). ${ }^{11}$ The catalysts operate well at pressures around 10 bar and above (Fig. S5). The hydrogen is in excess, but further increases in hydrogen pressure lead to faster rates (i.e. the reactions have a positive order in hydrogen (presumably 1 ), although not measured as an excess reagent). Increasing concentration of base (Fig, S6) is beneficial up to a certain level then becomes less important presumably due to solubility.

\section{Transfer hydrogenation}

In order to confirm that this pronounced electronic effect on the rates of reaction was solely originating in improved hydrogen activation, the transfer hydrogenation of propiophenone was also studied using catalysts 1, 9, 10 and 11. Initial individual batch experiments stopped just before reaching full conversion indeed suggests there are no longer huge differences in reactivity between the 1, $\mathbf{9}$ and $\mathbf{1 0}$ catalysts in this reaction (Table S3). This is confirmed by the graphs of conversion versus time (Fig. 3 ) that are very similar and give consistent with a first order dependence in substrate concentration. We used $\mathrm{KO}^{t} \mathrm{Bu}$ as the activator / base with these experiments as $\mathrm{K}_{2} \mathrm{CO}_{3}$ was did not activate the catalyst under the reaction conditions $(0.2 \mathrm{~mol} \%$ catalyst, $5 \mathrm{~mol} \%$ base, $50{ }^{\circ} \mathrm{C}$, isopropanol).

The data show that there are only small differences in TOF and enantioselectivity between catalysts $\mathbf{1}, \mathbf{9}$ and $\mathbf{1 0}$. This indicated that the nature of the phosphines has more of an impact on hydrogenation of ketones than under transfer hydrogenation conditions, since the electronic effects impact on the hydrogen activation. Catalyst $\mathbf{1 1}$ was found to be quickly deactivated during the reaction and failed to go to $>60 \%$ conversion after $5 \mathrm{~h}$ reaction time. In a separate experiment, a lower amount of $\mathrm{KO}^{t} \mathrm{Bu}$ was used, but this gave even poorer conversion (Fig. 3 entry 5). Using potassium hydroxide as the base showed minimal conversion after $2 \mathrm{~h}$ (Fig. 3 entry 6). Transfer hydrogenations using manganese catalyst have attracted significant interest recently. ${ }^{4(h), 5(k)-(m)}$ Catalyst 1 appears to have broadly similar activity, but our catalysts are more selective and productive in pressure hydrogenation. Further results for transfer hydrogenation are archived in Table S3. 
<smiles>CC[C@H](O)c1cccc(C#CCCCC(=O)c2ccccc2)c1</smiles>

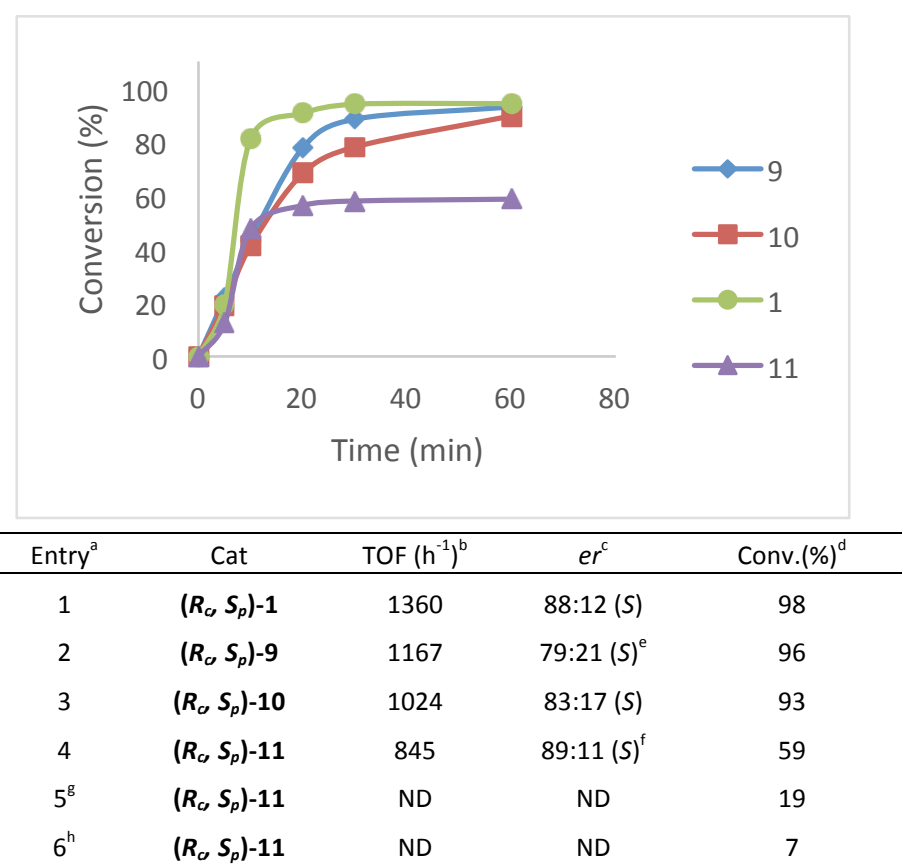

a. Typical reaction conditions: $3.00 \mathrm{mmol}$ substrate, $0.006 \mathrm{mmol}$ catalyst, 0.15 $\mathrm{mmol} \mathrm{KO} \mathrm{B}^{\mathrm{B} u}$ and internal standard $(0.06 \mathrm{mmol})$ isopropanol $(0.3 \mathrm{M}) 50^{\circ} \mathrm{C}$ for $5 \mathrm{~h}$; b. Calculated from conversion after 20 min reaction time; c. e.r. was measured using chiral HPLC, known absolute configuration of the major enantiomer in brackets; $d$. Conversion after $5 \mathrm{~h}$ reaction time; e. the e.r. was determined to be 88:12 (S) under hydrogenation conditions; $f$. the e.r. was determined to be $86: 14$ (S) under hydrogenation conditions; g. 2 mol\% KO ${ }^{t} \mathrm{Bu}$ as base; h. $5 \mathrm{~mol} \% \mathrm{KOH}(\mathrm{s})$ as base.

Fig. 3. Conversion over time for the transfer hydrogenation of propiophenone using $\mathrm{Mn}$ complexes 1, 9, 10 and $\mathbf{1 1}$

\section{Ester hydrogenation}

Since 1 is a good catalyst for the reduction of esters ${ }^{4(q)}$ we were curious as to the outcome of ester hydrogenation using catalysts 1 and 9-11 (Fig. 4 and 5).

Since ester hydrogenation was found to be first order in substrate using catalyst, $\mathbf{1}$ (Fig. 4 and 5 ) then it is also expected that smaller differences between the catalysts would be observed, since activation of dihydrogen was no longer rate determining. 1 and $\mathbf{9}$ are indeed similar but $\mathbf{1 0}$ or $\mathbf{1 1}$ did not reach complete conversion easily (Fig. 4). The kinetics of ethyl para-fluorobenzoate hydrogenation at $90{ }^{\circ} \mathrm{C}$ were complicated by catalyst 11 showing evidence of decomposition. The original curves of conversion versus time are reprocessed in the form of plots of TOF against [S] during the catalytic reaction (i.e. the beginning of the reaction [S] is around $0.5 \mathrm{M}$ ). Fig. 5, red line shows that the rate in this experiment drops off faster than would be predicted given the ester hydrogenation was first order in substrate, unlike the rate data for catalyst 1.

Catalyst 1 shows quite good stability and a fairly linear relationship between TOF and [S]. Excess experiments reveal there is no product inhibition but some evidence of the catalyst beginning to degrade after several hours, since the TOF measured at $[\mathrm{S}]=0.15 \mathrm{M}$ after $6.5 \mathrm{~h}$ is lower than after 1.7 h (Table 5 entry 2 and 3 ).
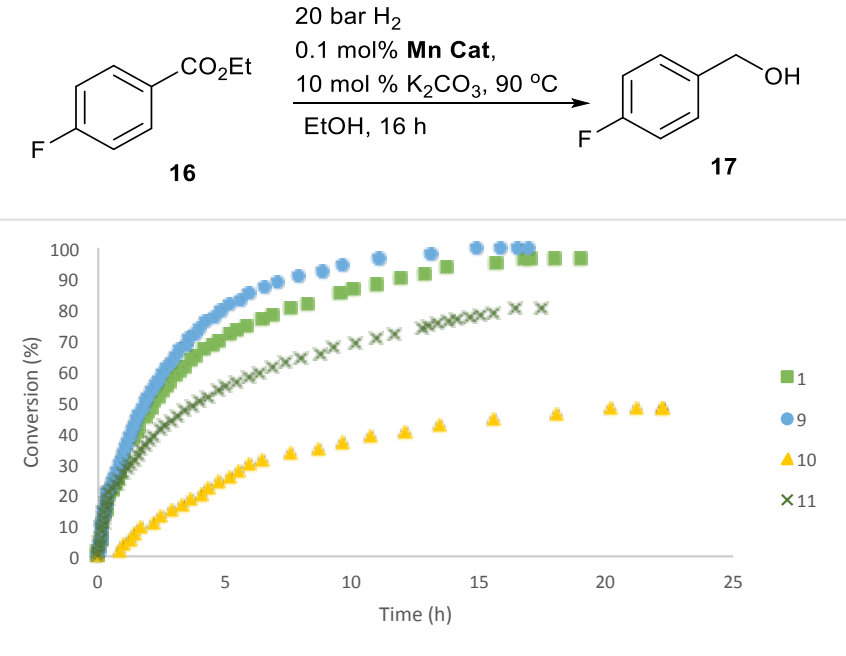

Experimental conditions: $20.81 \mathrm{mmol}$ ethyl $p$-fluorobenzoate, $0.021 \mathrm{mmol}$ catalyst, $2.08 \mathrm{mmol} \mathrm{K}_{2} \mathrm{CO}_{3}, 20$ bar $\mathrm{H}_{2}, 90{ }^{\circ} \mathrm{C}, 16 \mathrm{~h}$, ethanol $(0.62 \mathrm{M})$;

Fig. 4. Conversion over time for the hydrogenation of ethyl $p$-fluorobenzoate (16) using Mn complexes 1, 9, 10 and 11.

Table 5. Excess experiments using catalyst $\mathbf{1}^{\mathrm{a}}$

\begin{tabular}{ccc}
\hline$[\mathrm{S}]_{0}^{\mathrm{b}}$ & Reaction Time $(\mathrm{h})^{\mathrm{c}}$ & TOF at $[\mathrm{S}]=0.15 \mathrm{M}\left(\mathrm{h}^{-1}\right)$ \\
\hline $0.62 \mathrm{M}$ & 6.5 & 122 \\
$0.31 \mathrm{M}$ & 1.7 & 143 \\
$0.31 \mathrm{M}^{\mathrm{d}}$ & 1.8 & 139
\end{tabular}

a. Experimental conditions: 10.41-20.81 mmol ethyl p-fluorobenzoate, 0.021 mmol 1, $2.08 \mathrm{mmol} \mathrm{K}_{2} \mathrm{CO}_{3}, 20$ bar $\mathrm{H}_{2}, 90^{\circ} \mathrm{C}, 16 \mathrm{~h}$, ethanol (0.3-0.6 M); b. starting concentration of substrate; c. time at which $[\mathrm{S}]=0.15 \mathrm{M}$; d. 50/50 mixture of substrate and product

This decomposition / deactivation pathway is more pronounced for $\mathbf{1 1}$ as evident by TOF dropping off as reaction progressed (Fig. 5 red). The reaction of $\mathbf{1 1}$ was monitored using gas uptake at 70 and $90{ }^{\circ} \mathrm{C}$ (Fig. S7), and this clearly shows the decomposition and lowering of the rate with time at $90{ }^{\circ} \mathrm{C}$ as opposed to normal first order kinetics at $70{ }^{\circ} \mathrm{C}$. The $\mathrm{TOF}_{20 \%}$ for $\mathbf{1 1}$ at 70 and $90{ }^{\circ} \mathrm{C}$ was found to be nearly the same (Table 6 entries 5 and 6 ).

Table 6 show that experiments show that $\mathbf{1 1}$ was more active than the other catalysts followed by catalyst $\mathbf{9}$ at lower temperature. The TOF and the fact that the reaction using $\mathbf{1 1}$ as catalyst failed to go to full conversion at $90{ }^{\circ} \mathrm{C}$ but did so at $70{ }^{\circ} \mathrm{C}$ clearly showed that $\mathbf{1 1}$ was unstable at temperatures $>75{ }^{\circ} \mathrm{C}$. It may find some niche for ester hydrogenations that need lower temperatures, but preparative ester reductions can be carried out to good effect using $0.1 \mathrm{~mol} \%$ catalyst loading at $90{ }^{\circ} \mathrm{C}$ using the more stable catalyst 9. A few examples on ester hydrogenation promoted by the new catalyst can be found below (Scheme 4). 
<smiles>CCOc1ccc(F)cc1</smiles>

16

20 bar $\mathrm{H}_{2}$

$0.1 \mathrm{~mol} \% \mathrm{Mn}$ Cat,

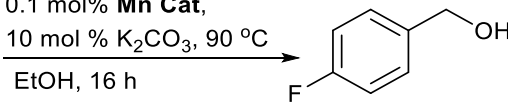

17

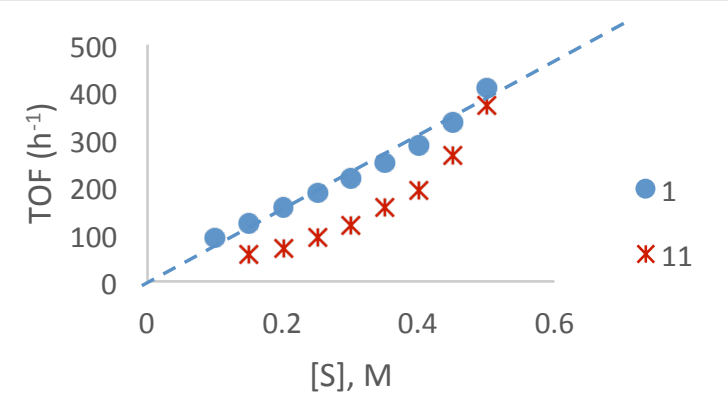

Experimental conditions: $20.81 \mathrm{mmol}$ ethyl $p$-fluorobenzoate, $0.021 \mathrm{mmol}$ catalyst, $2.08 \mathrm{mmol} \mathrm{K}_{2} \mathrm{CO}_{3}, 20$ bar $\mathrm{H}_{2}, 90{ }^{\circ} \mathrm{C}, 16 \mathrm{~h}$, ethanol $(0.62 \mathrm{M})$;

Fig. 5. TOF vs [S] for the hydrogenation of ethyl p-fluorobenzoate using catalyst 1 and $\mathbf{1 1}$ (data obtained from two experiments by calculating [S] based on conversion data).

Table 6. Comparing the activity of $\mathrm{Mn}$ catalysts in ester hydrogenation at 70 ${ }^{\circ} \mathrm{C}^{\mathrm{a}}$

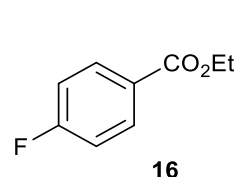

20 bar $\mathrm{H}_{2}$

$0.1 \mathrm{~mol} \% \mathrm{Mn}$ Cat,

$\underset{\mathrm{EtOH}, 5 \mathrm{~h}}{10 \mathrm{~mol} \% \mathrm{~K}_{2} \mathrm{CO}_{3}, 70^{\circ} \mathrm{C}}$

\begin{tabular}{ccccc}
\hline Entry & Catalyst & ${\text { Conv. }(\%)^{\mathrm{b}}}$ & Prod. $(\%)^{\mathrm{b}}$ & ${\text { TOF }\left(\mathrm{h}^{-1}\right)^{\mathrm{c}}}^{\mathrm{c}}$ \\
\hline 1 & $\mathbf{1}$ & 11.5 & 10.5 & 22 \\
2 & 9 & 25 & 21 & 46 \\
3 & 10 & 9.3 & 7.9 & 17 \\
4 & 11 & 46.7 & 43.3 & 90 \\
$5^{\mathrm{d}}$ & 11 & 20 & 20 & $368^{\mathrm{d}}$ \\
$6^{\mathrm{e}}$ & 11 & 20 & 20 & $372^{\mathrm{e}}$ \\
$7^{\mathrm{e}}$ & 9 & 20 & 20 & 490
\end{tabular}

a. Experimental conditions: $1.78 \mathrm{mmol}$ ethyl $p$-fluorobenzoate, $0.002 \mathrm{mmol}$ catalyst, $0.18 \mathrm{mmol} \mathrm{K}_{2} \mathrm{CO}_{3}, 30 \mu \mathrm{L}$ internal standard (1-methylnaphthalene), 50 bar $\mathrm{H}_{2}, 70{ }^{\circ} \mathrm{C}, 5 \mathrm{~h}$, ethanol $(0.6 \mathrm{M})$; b. determined by ${ }^{1} \mathrm{H}-\mathrm{NMR}$ using internal standard; c. Calculated from conversion at $5 \mathrm{~h}$ reaction time using vessel with magnetic stirring; d. calculated from gas uptake data at $20 \%$ conversion at $70{ }^{\circ} \mathrm{C}$ in mechanically-stirred vessel ( $>99 \%$ conversion after $17 \mathrm{~h}$ ); e. calculated from gas uptake data at $20 \%$ conversion at $90{ }^{\circ} \mathrm{C}$ in mechanically-stirred vessel.

Sclareolide (18a) was readily reduced under the reaction conditions (0.1 mol\% 9, 10 mol\% $\mathrm{K}_{2} \mathrm{CO}_{3}, 50$ bar $\mathrm{H}_{2}, 90{ }^{\circ} \mathrm{C}$ in ethanol). This is similar performance to the previously communicated experiment using catalyst 1 at 5 gram scale (archived in the ESI for completeness). Ethyl 1-naphthanoate was also reduced at $90{ }^{\circ} \mathrm{C}$ to the alcohol with good conversion (18b) was shown to be readily reduced. Ethyl nicotinate (18c) and yield. Ethyl dihydrocinnamate (18d) was also readily hydrogenated at $90{ }^{\circ} \mathrm{C}$. Using published conditions, (S)-ethyl naproxen (18e) was reduced using either $1.0 \mathrm{~mol} \%$ or 0.5 mol\% 9 with similar e.r. as reported using Mn complex $1 .^{4(q)}$ Finally, dihydrocoumarin (18f) was tested and found to be only converted in $76 \%$ to product under the reaction conditions with the remaining substrate had been converted to the ethyl ester. The final substrate was ethyl $p$-iodobenzoate $(\mathbf{1 8 g})$ which was reduced to the $p$-iodobenzyl alcohol in excellent yields.
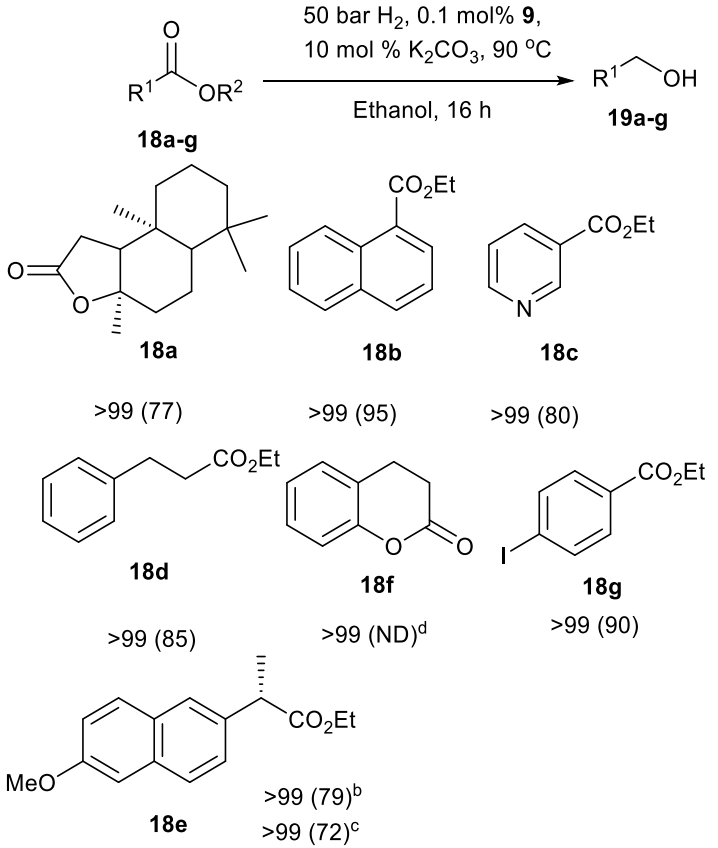

a. Typical reaction conditions: $1.40 \mathrm{mmol}$ substrate, $0.0014 \mathrm{mmol} 9,0.14 \mathrm{mmol} \mathrm{K}{ }_{2} \mathrm{CO}_{3}$ and internal standard $(0.06 \mathrm{mmol})$ in ethanol $(0.5 \mathrm{M})$ under 50 bar of $\mathrm{H}_{2}$ at $90{ }^{\circ} \mathrm{C}$ for 16 h; Conversion was estimated by ${ }^{1} \mathrm{H}-\mathrm{NMR}$ using 1 -methylnaphthalene as internal standard; Isolated yield in brackets, ND = not determined; b. reaction run with $1 \mathrm{~mol} \%$ 9 in isopropanol, e.r. was determined by chiral HPLC to be 99.3:0.7 (S); c. reaction run with $0.5 \mathrm{~mol} \% 9$ in isopropanol, e.r. was determined by chiral HPLC to be $98: 2$ (S); d. 76 $\%$ product, the rest the ethyl ester.

Scheme 4. Ester hydrogenation using Mn complex $9^{a}$

Returning to ketone hydrogenation, the scope of the secondgeneration ketone hydrogenation catalyst $\mathbf{1 1}$ is summarized in Tables 7 and 8 with standard conditions of 0.1 mol\% catalyst, $16 \mathrm{~h}$ reaction time and $50{ }^{\circ} \mathrm{C}$ reaction temperature for most examples. Using acetophenone as substrate we were able to reduce the catalyst loading to 0.02 and even $0.01 \mathrm{~mol} \%$ albeit at higher temperature (60 and $65{ }^{\circ} \mathrm{C}$, Table 7, entries 2-3). Substitution on the aromatic ring was investigated next and we found that ortho substituted ketones were reduced with lower enantioselectivity than either meta or para substituted ketones (Table 7, entries 4-8). Both bromine and iodide substituted acetophenone could be tolerated (Table 7 entries 9-10). 4'-cyanoacetophenone could be reduced to full conversion at $30{ }^{\circ} \mathrm{C}$ but with $\sim 7 \%$ by-product which was tentatively assigned as the ethyl ester (Table 7, entry 11). This chemoselectivity for $\mathrm{C}=\mathrm{O}$ over nitrile reduction is interesting, 
since some $\mathrm{Mn}$ catalysts are known to reduce nitriles well. ${ }^{3 b}$ We note here also that attempts to hydrogenate imines were entirely unsuccessful using these catalysts. 2,6-dichloro-3fluoroacetophenone (Table 7 , entry 12 ) was readily reduced with an er of 91:9 (S). The product alcohol (21i) is a component in the synthesis of the pharmaceutical Critozinib. ${ }^{12}$ The 3,4,5trimethoxyacetophenone (20j Table 7, entry 13$)$ was reduced to a product with er of 90:10 (S).

Table 7. Ketone hydrogenation using Mn complex $11^{a}$

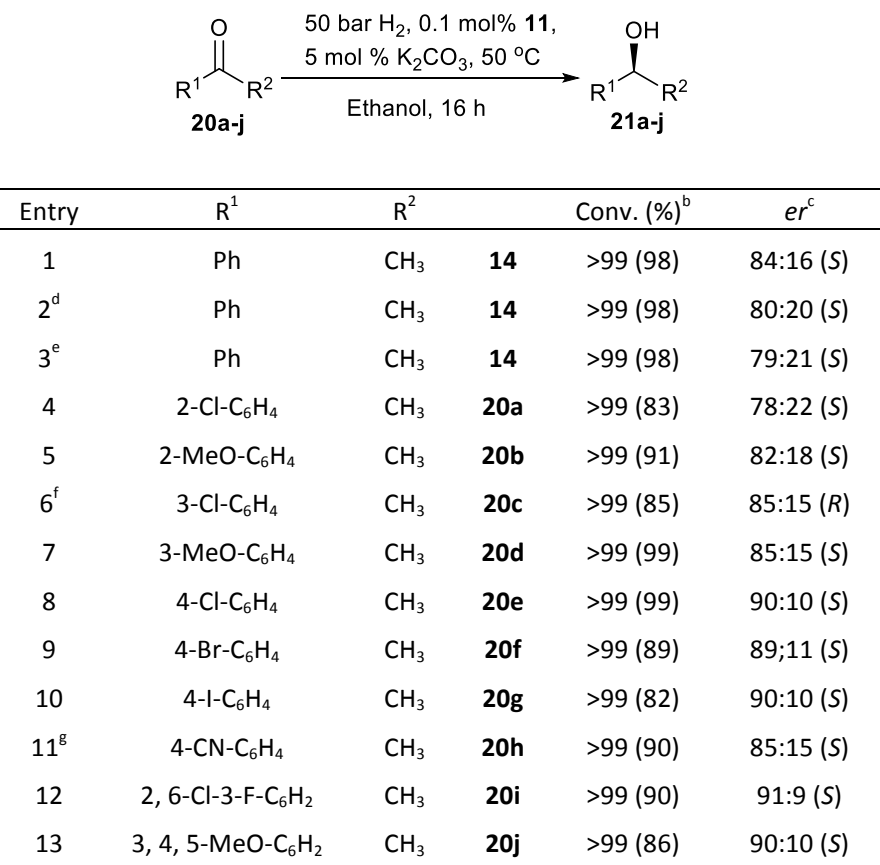

Typical reaction conditions: $1.36 \mathrm{mmol}$ substrate, $0.0014 \mathrm{mmol}\left(\boldsymbol{R}_{c}, \boldsymbol{S}_{p}\right)-\mathbf{1 1}, 0.068$ mmol $\mathrm{K}_{2} \mathrm{CO}_{3}$ and internal standard $(0.06 \mathrm{mmol}), 50$ bar $\mathrm{H}_{2}$, ethanol $(0.67 \mathrm{M}), 50$ ${ }^{\circ} \mathrm{C}, 16 \mathrm{~h}$; b. conversion determined by ${ }^{1} \mathrm{H}-\mathrm{NMR}$ using internal standard; c. e.r. was measured using chiral HPLC, known absolute configuration of the major enantiomer in brackets; d. $0.02 \mathrm{~mol} \% 11$ at $60{ }^{\circ} \mathrm{C}$ for $24 \mathrm{~h}$; e. $0.01 \mathrm{~mol} \% 11$ at 65 ${ }^{\circ} \mathrm{C}$ for $24 \mathrm{~h}$; f. using $\left(S_{c}, R_{p}\right)-11$; g. reaction run at $30^{\circ} \mathrm{C}$.

The results from hydrogenation of ketones with $\mathrm{R}^{2}$ substituents other than methyl are shown in Table 8. Propiophenone (20k) was reduced with an er of 86:14 (S), whilst both 4'chloropropiophenone (201) and 4'-methoxypropiophenone (20m) gave products with slightly higher er (93:7 and 91:9, Table 8, entries $1-3$ ). The base sensitive $N, N$-dimethyl-3aminopropiophenone (200) a precursor to fluoxetine ${ }^{13}$ was readily reduced under the reaction conditions with an er of 86:14 (S) (Table 8, entry 6). N, N- dimethyl-3-amino-1-(4chlorophenyl)propiophenone (20p, Table 8 , entry 7) gave a product with an er of 89:11. 1-(4-bromophenyl)-3-piperidin-1ylpropiophenone (20q) was also reduced with good enantioselectivity and yield (Table 8 , entry 8 ). The bulkier ketones isobutyrophenone, 2,2,2-trimethylacetophenone (20r) and cyclohexylphenyl ketone (20s) (Table 8, entries 4-5 and 911) gave alcohols with good er using either $\left(\boldsymbol{R}_{c} \boldsymbol{S}_{p}\right)$-9 or $\left(\boldsymbol{R}_{c} \boldsymbol{S}_{p}\right)$ 11 with slightly higher er observed for $\left(\boldsymbol{R}_{c}, \boldsymbol{S}_{p}\right)$-9. The final entry 2-methyl-1-phenylpropiophenone (20t) gave an alcohol product (21t) with an er of 91:9. The enantioselectivity is biased towards $(R)$ for $\left(S_{c}, R_{p}\right)-\mathbf{1}$ and $(S)$ for $\left(\boldsymbol{R}_{c}, S_{p}\right)$-9-13. There is no discernible impact on the enantioselectivity from altering the aryl groups on the phosphine.

Table 8. Ketone hydrogenation using $\mathrm{Mn}$ complex $\mathbf{1 1}^{\mathrm{a}}$

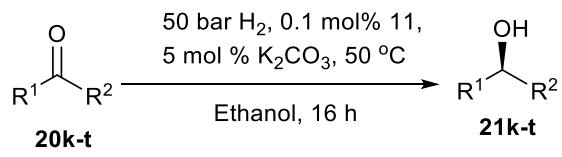

\begin{tabular}{|c|c|c|c|c|c|}
\hline Entry & $\mathrm{R}^{1}$ & $\mathrm{R}^{2}$ & & $\begin{array}{c}\text { Conv. } \\
(\%)^{b}\end{array}$ & $e r^{c}$ \\
\hline 1 & $\mathrm{Ph}$ & $\mathrm{CH}_{2} \mathrm{CH}_{3}$ & $20 \mathrm{k}$ & $>99(81)$ & $86: 14$ \\
\hline 2 & $4-\mathrm{Cl}-\mathrm{C}_{6} \mathrm{H}_{4}$ & $\mathrm{CH}_{2} \mathrm{CH}_{3}$ & 201 & $>99(86)$ & $93: 7$ \\
\hline 3 & 4- $\mathrm{MeO}-\mathrm{C}_{6} \mathrm{H}_{4}$ & $\mathrm{CH}_{2} \mathrm{CH}_{3}$ & $20 \mathrm{~m}$ & $>99$ (89) & $91: 9$ \\
\hline 4 & $\mathrm{Ph}$ & $\mathrm{CH}\left(\mathrm{CH}_{3}\right)_{2}$ & $20 n$ & $>99(96)$ & $82: 18$ \\
\hline $5^{d}$ & $\mathrm{Ph}$ & $\mathrm{CH}\left(\mathrm{CH}_{3}\right)_{2}$ & $20 n$ & $>99(85)$ & $93: 7$ \\
\hline 6 & $\mathrm{Ph}$ & $\mathrm{CH}_{2} \mathrm{CH}_{2} \mathrm{~N}\left(\mathrm{CH}_{3}\right)_{2}$ & 200 & $>99$ (89) & $86: 14$ \\
\hline 7 & $4-\mathrm{Cl}-\mathrm{C}_{6} \mathrm{H}_{4}$ & $\mathrm{CH}_{2} \mathrm{CH}_{2} \mathrm{~N}\left(\mathrm{CH}_{3}\right)_{2}$ & $20 p$ & $>99(82)$ & $89: 11$ \\
\hline 8 & 4-Br- $-\mathrm{C}_{6} \mathrm{H}_{4}$ & $\mathrm{CH}_{2} \mathrm{CH}_{2} \mathrm{~N}\left(\mathrm{CH}_{2}\right)_{5}$ & $20 q$ & $>99(84)$ & $90: 10$ \\
\hline 9 & $\mathrm{Ph}$ & $\mathrm{C}\left(\mathrm{CH}_{3}\right)_{3}$ & $20 r$ & >99 (97) & $90: 10$ \\
\hline $10^{d}$ & $\mathrm{Ph}$ & $\mathrm{C}\left(\mathrm{CH}_{3}\right)_{3}$ & $20 r$ & $>99(85)$ & $93: 7$ \\
\hline 11 & $\mathrm{Ph}$ & $\mathrm{CH}\left(\mathrm{CH}_{2}\right)_{5}$ & $20 \mathrm{~s}$ & $>99(89)$ & $91: 9$ \\
\hline 12 & $\mathrm{Ph}$ & $\mathrm{C}\left(\mathrm{CH}_{3}\right)_{2} \mathrm{Ph}$ & $20 \mathrm{t}$ & $>99(85)$ & $91: 9$ \\
\hline
\end{tabular}

Typical reaction conditions: $1.36 \mathrm{mmol}$ substrate, $0.0014 \mathrm{mmol}$

$\left(\boldsymbol{R}_{\boldsymbol{c}} \boldsymbol{S}_{\boldsymbol{p}}\right)$-11, $0.068 \mathrm{mmol} \mathrm{K}_{2} \mathrm{CO}_{3}$ and internal standard (0.06 mmol), 50 bar $\mathrm{H}_{2}$, ethanol $(0.67 \mathrm{M}), 50{ }^{\circ} \mathrm{C}, 16 \mathrm{~h}$; b. conversion determined by ${ }^{1} \mathrm{H}-\mathrm{NMR}$ using internal standard; c. er was measured using chiral HPLC; d. $\left(\boldsymbol{R}_{\boldsymbol{c}} \boldsymbol{S}_{p}\right)-\mathbf{9}$ used as catalyst.

We considered either a fac- or a mer- configuration of the ligand around the $\mathrm{Mn}$ hydride (Fig. 6). In the fac-coordination mode, if the aromatic moiety is aligned with the ligand pyridine in the $\left(S_{c}, R_{p}\right)-\mathbf{1}$ derived catalyst, the resulting alcohol will have the $(R)$-configuration. The alignment of the aromatic rings in a substrate with a heterocycle on a catalyst is quite widespread as an effective control element in asymmetric catalysis, ${ }^{14}$ although here substrates like acetophenone, that lack sterically different substituents give somewhat lower enantioselectivity. The model shows that a bulky substituent, $\mathrm{R}$, on the aliphatic side of the ketone, would stick out unhindered (Fig. 6, left). In the case of the mer-coordination mode the aliphatic part of the ketone is expected to clash with the phenyl groups on the phosphine. Since the substitution of the arylphosphine in the ligands also does not impact the enantioselectivity, the meridional structure seems unlikely, and we believe the fac-coordinated $\mathrm{Mn}$ hydride is more likely the correct form. Several attempts to detect or isolate this $\mathrm{Mn}$ hydride were unsuccessful. 


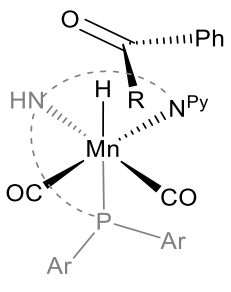

fac-

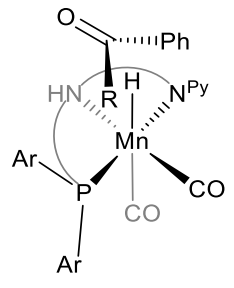

mer-
Fig. 6. Hypothetical fac- and mer- structures of the $\left(\boldsymbol{S}_{c}, \boldsymbol{R}_{p}\right) \mathbf{- 1}-\mathbf{H}$ with an aromatic ketone overlaid.

\section{Conclusions}

In conclusion, we have synthesised new $P, N, N$ ligands and successfully coordinated these to manganese, and deliver active hydrogenation catalysts. Kinetic studies indicate that for ketone hydrogenation the reaction was zero order in acetophenone, but first order with regards to the catalyst. In ester hydrogenation we found that the substrate and the catalyst was first order. Electronic effects on the rates of reaction have been studied and found to be profound. The introduction of an electron rich phosphine combined with an electron rich pyridine gave a very active $\mathrm{Mn}$ catalyst capable of hydrogenating acetophenone with as little as $0.01 \mathrm{~mol} \%$ catalyst load. This is competitive with any other earth abundant metal catalyst, to our knowledge. The lowest catalyst loadings for a Fe system for pressure hydrogenation seem to be $0.05 \mathrm{~mol} \%{ }^{2 n}$ while Fe-based ester hydrogenation catalyst use $1 \mathrm{~mol} \%$ of catalyst or higher. ${ }^{2 \mathrm{~s}}$ After this work was completed, another $\mathrm{Mn}$ system has been reported to operate readily at $1 \mathrm{~mol} \%$ of loading, but with an example at $0.01 \mathrm{~mol} \%$ using alkoxide base as a promoter. ${ }^{4 s}$ The exact mechanism for reduction using a variety of $\mathrm{Mn}$ systems would benefit from further elucidation in the future; it seems essential than a $\mathrm{CO}$ ligand leaves the $\mathrm{Mn}$ to be replaced with an $\mathrm{Mn}$-hydride. It seems reasonable that dihydrogen could bind to the $\mathrm{Mn}$ complex, which maybe more Lewis acidic than analogous Ru or Ir complexes. As a result of this deprotonation of this dihydrogen can be readily accomplished with just a weak base. While this becomes possible for this $\mathrm{Mn}$ catalyst (rather than impossible with $\mathrm{Ru}$ ), the kinetic studies show this step is more energetic than the reduction step for acetopheneone reduction, since the reactions are zero order in this substrate.

Catalyst stability has also been studied to clarify the temperature range that the catalysts should be used at. Quantifying catalyst stability by studying TOF versus [S] at different temperatures is perhaps underused as a means to ensure a catalyst behaves predictably.

A wide variety of functional groups within ketone and ester substrates can be tolerated using the new catalyst and the mild and economic reaction conditions (ethanol solvent, $\mathrm{K}_{2} \mathrm{CO}_{3}$ base). As higher enantioselectivity is often desirable for many applications, it is envisaged structural modification of $\mathrm{Mn}$ / $\mathrm{P}, \mathrm{N}, \mathrm{N}$ systems is likely to lead to improved enantioselectivity. Hopefully this can be done in a way that retains the key lessons from this work to ensure reactivity and stability. For the well-established substrates, the catalyst loadings used are not competitive with the most productive examples using precious metal catalysts. However, the possibility of a lower catalyst cost per gram, lower purification cost, alongside the use of economic additives and functional group tolerance does at least open the possibility that $\mathrm{Mn}$ catalysts might be assessed for large scale usage, or only need further research that is readily within reach to reach that level.

\section{Conflicts of interest}

There are no conflicts to declare

\section{Acknowledgements}

We are very grateful for the donation of ligand precursors from Solvias AG. The authors would like to thank Dr Anna Serra-Pont (Institute of Advanced Chemistry of Catalonia (IQAC-CSIC)) for her high-quality work on a related catalyst in the early stages of this project, during a short placement in St Andrews. The authors thank EPSRC (grant code: 1654521) for DTG funding for MBW.

\section{Notes and references}

₹ Footnotes relating to the main text should appear here. These might include comments relevant to but not central to the matter under discussion, limited experimental and spectral data, and crystallographic data.

1 (a) W. S. Knowles, R. Noyori, Acc. Res. Chem., 2007, 40, 12381239. (b) T. Ohkuma, H. Ooka, M. Yamakawa, T. Ikariya, R. Noyori, J. Org. Chem., 1996, 61, 4872-4873. (c) L. Saudan, Acc. Chem. Res., 2007, 40, 1309-1319. (d) N. B. Johnson, I. C. Lennon, P. H. Moran, J. A. Marsden, Acc. Chem. Res., 2007, 40, 1291-1299. (e) M. L. Clarke, Catal. Sci. Technol., 2012, 2, 2418.

2 (a) N. Gorgas, B. Stöger, L. F. Veiros and K. Kirchner, ACS Catal., 2016, 6, 2664-2672. (b) A. A. Mikhailine and R. H. Morris, Inorg. Chem., 2010, 49, 11039-11044. (c) R. Langer, G. Leitus, Y. Ben-David and D. Milstein, Angew. Chem. Int. Ed., 2011, 50, 2120-2124. (d) X. Yang, Inorg. Chem., 2011, 50, 12836-12843. (e) M. Darwish and M. Wills, Catal. Sci. Technol., 2012, 2, 243-255. (f) R. Langer, M. A. Iron, L. Konstantinovski, Y. Diskin-Posner, G. Leitus, Y. Ben-David and D. Milstein, Chem.-Eur. J., 2012, 18, 7196-7209. (g) S. Yu, W. Shen, Y. Li, Z. Dong, Y. Xu, Q. Li, J. Zhang and J. Gao, Adv. Synth. Catal., 2012, 354, 818-822. (h) R. M. Bullock, Science, 2013, 342, 1054-1055. (i) S. Fleischer, S. Zhou, K. Junge and M. Beller, Angew. Chem., Int. Ed., 2013, 52, 5120-5124. (j) D. S. Mérel, M. Elie, J.-F. Lohier, S. Gaillard and J.-L. Renaud, ChemCatChem, 2013, 5, 2939-2945. (k) W. Zuo, A. J. Lough, Y. F. Li and R. H. Morris, Science, 2013, 342, 1080-1083. (I) S. Chakraborty, H. Dai, P. Bhattacharya, N. T. Fairweather, M. S. Gibson, J. A. Krause and H. Guan, J. Am. Chem. Soc., 2014, 136, 7869-7872. (m) N. Gorgas, B. Stöger, L. F. Veiros, E. Pittenauer, G. Allmaier and K. Kirchner, Organometallics, 2014, 33, 6905-6914. (n) P. O. Lagaditis, P. E. Sues, J. F. Sonnenberg, K. Y. Wan, A. J. Lough and R. H. Morris, J. Am. Chem. Soc., 2014, 136, 1367-1380. (o) Y. Li, S. Yu, X. Wu, J. Xiao, W. Shen, Z. Dong and J. Gao, J. Am. Chem. Soc., 2014, 136, 4031-4039. (p) S. Werkmeister, K. Junge, B. Wendt, E. Alberico, H. Jiao, W. Baumann, H. Junge, F. Gallou and M. 
Beller, Angew. Chem., Int. Ed., 2014, 53, 8722-8726. (q) L. C. Misal Castro, H. Li, J.-B. Sortais and C. Darcel, Green Chem., 2015, 17, 2283-2303. (r) G. Bauer and X. Hu, Inorg. Chem. Front., 2016, 3, 741-765. (s) S. Elangovan, B. Wendt, C. Topf, S. Bachmann, M. Scalone, A. Spannenberg, H. Jiao, W. Baumann, K. Junge and M. Beller, Adv. Synth. Catal., 2016, 358, 820-825. (t) A. Zirakzadeh, K. Kirchner, A. Roller, B. Stöger, M. Widhalm and R. H. Morris, Organometallics, 2016 35, 3781-3787. (u) S. A. M. Smith, P. O. Lagaditis, A. Lupke, A. J. Lough and R. H. Morris, Chem.-Eur. J., 2017, 23, 7212-7216. (v) R. Huber, A. Passera, E. Gubler and A. 35 Synth. Catal., 2018, 360, 2900-2913. (w) R. Huber, A. Passera and A. Mezzetti, Organometallics, 2018, 37, 396-405. (x) A. Lator, S Gaillard, A. Poater and J. L. Renaud, Chem.-Eur. J., 2018, 24, 5770-5774. (y) Y. Yi, H. Liu, L. P. Xiao, B. Wang and G. Song, ChemSusChem, 2018, 11, 1474-1478. (z) G. Zhang, B. L. Scott and S. K. Hanson, Angew. Chem. Int. Ed. Engl., 2012, 51, 12102-12106. (xx) G. Zhang and S. K. Hanson, Chem. Commun., 2013, 49, 10151-10153. (xy) S. S. Rozenel, R. Padilla, C. Camp and J. Arnold, Chem. Commun., 2014, 50, 2612-2614. (xz) C. Hou, J. Jiang, Y. Li, Z. Zhang, C. Zhao and Z. Ke, Dalton Trans., 2015, 44, 16573-16585. (yz) T. J. Korstanje, J. I. van der Vlugt, C. J. Elsevier and B. de Bruin, Science, 2015, 350, 298-302. (yy) K. Junge, B. Wendt, A. Cingolani, A. Spannenberg, Z. Wei, H. Jiao and M. Beller, Chem.-Eur. J., 2018, 24, 1046-1052.

3 (a) S. Elangovan, M. Garbe, H. Jiao, A. Spannenberg, K. Junge and M. Beller, Angew. Chem. Int. Ed. Engl., 2016, 55, 1536415368. (b) S. Elangovan, C. Topf, S. Fischer, H. Jiao, A Spannenberg, W. Baumann, R. Ludwig, K. Junge and $M$ Beller, J. Am. Chem. Soc., 2016, 138, 8809-8814. (c) F. Kallmeier, T. Irrgang, T. Dietel and R. Kempe, Angew. Chem. Int. Ed. Engl., 2016, 55, 11806-11809.

4 (a) A. Kaithal, M. Holscher, W. Leitner, Angew. Chem., 2018 , 130, 13637-13641. (b) A. Bruneau-Voisine, D. Wang, T. Roisnel, C. Darcel and J.-B. Sortais, Catal. Commun., 2017, 92 1-4. (c) A. Dubey, L. Nencini, R. R. Fayzullin, C. Nervi and J. R. Khusnutdinova, ACS Catal., 2017, 7, 3864-3868. (d) N. A. Espinosa-Jalapa, A. Nerush, L. J. W. Shimon, G. Leitus, L. Avram, Y. Ben-David and D. Milstein, Chem.-Eur. J., 2017, 23, 5934-5938. (e) M. Garbe, K. Junge, S. Walker, Z. Wei, H. Jiao, A. Spannenberg, S. Bachmann, M. Scalone and M. Beller, Angew. Chem. Int. Ed. Engl., 2017, 56, 11237-11241. (f) S. Kar, A. Goeppert, J. Kothandaraman and G. K. S. Prakash, ACS Catal., 2017, 7, 6347-6351. (g) V. Papa, J. R. CabreroAntonino, E. Alberico, A. Spanneberg, K. Junge, H. Junge and M. Beller, Chem. Sci., 2017, 8, 3576-3585. (h) M. Perez, S. Elangovan, A. Spannenberg, K. Junge and $M$. Beller, ChemSusChem, 2017, 10, 83-86. (i) K. S. Rawat and B. Pathak, Catal. Sci. Technol., 2017, 7, 3234-3242. (j) R. van Putten, E. A. Uslamin, M. Garbe, C. Liu, A. Gonzalez-de-Castro, M. Lutz, K. Junge, E. J. M. Hensen, M. Beller, L. Lefort and E. A. Pidko, Angew. Chem. Int. Ed. Engl., 2017, 56, 7531-7534. (k) D. Wei, A. Bruneau-Voisine, T. Chauvin, V. Dorcet, T. Roisnel, D. A. Valyaev, N. Lugan and J.-B. Sortais, Adv. Synth. Catal., 2018 360, 676-681. (I) M. B. Widegren, G. J. Harkness, A. M. Z. Slawin, D. B. Cordes and M. L. Clarke, Angew. Chem. Int. Ed. Engl., 2017, 56, 5825-5828. (m) M. Glatz, B. Stoger, D. Himmelbauer, L. F. Veiros and K. Kirchner, ACS Catal., 2018, 8, 4009-4016. (n) N. Gorgas and K. Kirchner, Acc. Chem. Res., 2018, 51, 1558-1569. (o) A. Kumar, T. Janes, N. A. EspinosaJalapa and D. Milstein, Angew. Chem. Int. Ed. Engl., 2018, 57, 12076-12080. (p) S. Weber, B. Stoger and K. Kirchner, Org. Lett., 2018, 20, 7212-7215. (q) M. B. Widegren and M. L. Clarke, Org. Lett., 2018, 20, 2654-2658. (r) V. Zubar, Y. Lebedev, L. M. Azofra, L. Cavallo, O. El-Sepelgy and M. Rueping, Angew. Chem. Int. Ed. Engl., 2018, 57, 1343913443. (s) L. Zhang, Y. Tang, Z. Han, K. Ding, Angew. Chem.
Int. Ed. Engl., 2019, 58, 4973-4977. (t) A. Kumar, T. Janes, N. A. Espinosa-Jalapa, D. Milstein, Angew. Chem. Int. Ed. Engl., 2018, 57, 12076-12080.

5 (a) M. Ito, T. Ootsuka, R. Watari, A. Shiibashi, A. Himizu and T. Ikariya, J. Am. Chem. Soc., 2011, 133, 4240-4242. (b) D. Spasyuk, C. Vicent and D. G. Gusev, J. Am. Chem. Soc., 2015, 137, 3743-3746. (c) S. Gao, W. Tang, M. Zhang, C. Wang and J. Xiao, Synlett, 2016, 27, 1748-1752. (d) C.-J. Hou and X.-P. $\mathrm{Hu}$, Org. Lett., 2016, 18, 5592-5595. (e) W. Wu, S. Liu, M. Duan, X. Tan, C. Chen, Y. Xie, Y. Lan, X.-Q. Dong and X. Zhang, Org. Lett., 2016, 18, 2938-2941. (f) X.-S. Chen, C.-J. Hou, C. Qin, H. Liu, Y.-J. Liu, D.-Z. Huang and X.-P. Hu, RSC Adv., 2017, 7, 12871-12875. (g) Y. Wang, G. Yang, F. Xie and W. Zhang, Org. Lett., 2018, 20, 6135-6139. (h) M. Cettolin, P. Puylaert, L. Pignataro, S. Hinze, C. Gennari and J. G. de Vries, ChemCatChem, 2017, 9, 3125-3130. (i) J. Yu, M. Duan, W. Wu, X. Qi, P. Xue, Y. Lan, X.-Q. Dong and X. Zhang, Chem.-Eur. J., 2017, 23, 970-975. (j) J. Yu, J. Long, Y. Yang, W. Wu, P. Xue, L. W. Chung, X. Q. Dong and X. Zhang, Org Lett, 2017, 19, 690-693. (k) A. Bruneau-Voisine, D. Wang, V. Dorcet, T. Roisnel, C. Darcel and J. B. Sortais, Org. Lett., 2017, 19, 36563659. (I) A. Zirakzadeh, S. R. M. M. de Aguiar, B. Stöger, M. Widhalm and K. Kirchner, ChemCatChem, 2017, 9, 17441748. (m) K. Z. Demmans, M. E. Olson and R. H. Morris, Organometallics, 2018, 37, 4608-4618. (n) D. Wang, A. Bruneau-Voisine and J.-B. Sortais, Catal. Commun., 2018, 105, 31-36. (o) O. Martinez-Ferras, C. Werle, G. Francio, W. Leitner, ChemCatChem, 2018, 10, 4514-4518.

6 Specification limits for residues of metal catalysts or metal reagents, Report CHMP/SWP/4446/2000, European Medicines Agency, 2008.

7 (a) Clarke, M. L.; Díaz-Valenzuela, M. B.; Slawin, A. M. Z., Organometallics, 2007, 26, 16-19. (b) Díaz-Valenzuela, M. B.; Phillips, S. D.; France M. B.; Gunn, M. E.; Clarke, M. L., Chem.Eur. J. 2009, 15, 1227-1232. (c) Fuentes, J. A.; Smith, S. M.; Scharbert, M. T.; Carpenter, I.; Cordes, D. B.; Slawin, A. M.; Clarke, M. L., Chem.-Eur. J. 2015, 21, 10851-60. (d) Fuentes, J. A.; Carpenter, I.; Kann, N.; Clarke, M. L., Chem. Commun. 2013, 49, 10245-10247.

8 (a) C-J. Hou, X-P Hu, Org. Lett. 2016, 18, 5592-5595. (b) W. Wu, S. Liu, M. Duan, X. Tan, C. Chen, Y. Xie, Y. Lan, X-Q. Dong, X. Zhang, Org. Lett. 2016, 18, 2938-1941. (c) Nie, H.; Zhou, G.; Wang, Q.; Chen, W.; Zhang, S., Tetrahedron-Asymmetr. 2013, 24, 1567-1571.

9 (a) Ito, M.; Ootsuka, T.; Watari, R.; Shiibashi, A.; Himizu, A.; Ikariya, T., J. Am. Chem. Soc. 2011, 133, 4240-4242. (b) Spasyuk, D.; Vicent, C.; Gusev, D. G., J. Am. Chem. Soc. 2015, 137, 3743-3746. (c) Gao, S.; Tang, W.; Zhang, M.; Wang, C.; Xiao, J., Synlett 2016, 27, 1748-1752. (d) Hou, C.-J.; Hu, X.-P., Org. Lett. 2016, 18, 5592-5595. (e) L. De Luca, L.; Mezzetti, A., Angew. Chem. Int. Ed. 2017, 56, 11949. (f) Chen, X.-S.; Hou, C.-J.; Qin, C.; Liu, H.; Liu, Y.-J.; Huang, D.-Z.; Hu, X.-P., RSC Adv. 2017, 7, 12871-12875. (g) Wang, Y.; Yang, G.; Xie, F.; Zhang, W., Org. Lett. 2018, 20, 6135-6139. (h) Cettolin, M.; Puylaert, P.; Pignataro, L.; Hinze, S.; Gennari, C.; de Vries, J. G., ChemCatChem 2017, 9, 3125-3130.

10 (a) Yu, J.; Long, J.; Yang, Y.; Wu, W.; Xue, P.; Chung, L. W.; Dong, X. Q.; Zhang, X., Org. Lett. 2017, 19, 690-693. (b) Marquading, D. K., H.; Gokel, G.; Hoffmann, P.; Ugi, I., J. Am. Chem. Soc. 1970, 92, 5389-593. (c) Gokel, G. W.; Marquarding, D.; Ugi, I. K., J. Org. Chem. 1972, 37, 30523058.

11 Burés, J., A Simple Graphical Method to Determine the Order in Catalyst. Angew. Chem., Int. Ed. 2016, 55 (6), 2028-2031.

12 P. D. de Koning, D. McAndrew, R. Moore, I. B. Moses, D. C. Boyles, K. Kissick, C. L. Stanchina, T. Cuthbertson, A. Kamatani, L. Rahman, R. Rodriguez, A. Urbina, A. Sandoval and P. R. Rose, Org. Process Res. Dev., 2011, 15, 1018-1026. 
13 (a) P. D. de Koning, M. Jackson and I. C. Lennon, Org. Process Res. Dev., 2006, 10, 1054-1058. (b) C. J. Wenthur, M. R. Bennett and C. W. Lindsley, ACS Chem. Neurosci., 2014, 5, 14-23.

14 S. F. Musolino, O. S. Ojo, N. J. Westwood, J. E. Taylor and A. D. Smith, Chem. Eur. J. 2016, 22, 18916-18922 